\title{
Hydro-Chemical Processes in Lake Qinghai throughout Climate Warming: In Situ Investigations of the Largest Lake in China
}

\section{Chuanfang Jin ${ }^{1,2}$, Shijie Li ${ }^{2,3}{ }^{*}$, Hongliang Zhang ${ }^{4}$, Jifeng Liu ${ }^{5}$, Wei Chen ${ }^{6}$, Yongjian Jiang7}

${ }^{1}$ State Key Laboratory of Palaeobiology and Stratigraphy, Nanjing Institute of Geology and Palaeontology, Chinese Academy of Sciences, Nanjing, China

${ }^{2}$ State Key Laboratory of Lake Science and Environment, Nanjing Institute of Geography and Limnology, Chinese Academy of Sciences, Nanjing, China

${ }^{3}$ State Key Laboratory of Environmental Geochemistry, Institute of Geochemistry, Chinese Academy of Sciences, Guiyang, China

${ }^{4}$ School of Resources Environment and Tourism, Anyang Normal University, Anyang, China

${ }^{5}$ Yellow River Conservancy Commission of the Ministry of Water Resources, Zhengzhou, China

${ }^{6}$ Key Laboratory of Economic Stratigraphy and Palaeogeography, Nanjing Institute of Geology and Palaeontology, Chinese Academy of Sciences, Nanjing, China

${ }^{7}$ School of Resources and Environment, Linyi University, Linyi, China

Email: *shjli@niglas.ac.cn

How to cite this paper: Jin, C.F., Li, S.J., Zhang, H.L., Liu, J.F., Chen, W. and Jiang, Y.J. (2016) Hydro-Chemical Processes in Lake Qinghai throughout Climate Warming: In Situ Investigations of the Largest Lake in China. Natural Science, 8, 574-590. http://dx.doi.org/10.4236/ns.2016.812056

Received: November 25, 2016

Accepted: December 25, 2016

Published: December 28, 2016

Copyright $\odot 2016$ by authors and Scientific Research Publishing Inc. This work is licensed under the Creative Commons Attribution International License (CC BY 4.0).

http://creativecommons.org/licenses/by/4.0/

\begin{abstract}
In the wake of climate warming, the water level of Lake Qinghai has been continuously and rapidly declining during the past decades, causing the regional government and citizens to worry about its future as a water resource. To understand the lake evolution process, the hydro-chemical characteristics of Lake Qinghai were investigated in August of 2008. The results show that $\mathrm{Na}^{+}$and $\mathrm{Cl}^{-}$are the dominant cations and anions in the lake water, respectively, and hydrochemistry type is $\mathrm{Cl}^{-}-\mathrm{Na}^{+}$ with an obvious characteristic of a saline lake. The Gibbs plot illuminates that evaporation/crystallization is responsible for the chemical composition of the lake water. The variation in hydro-chemical regime might be attributed to the reduced lake levels between 1960s and 2000s. The lake level significantly correlated with the precipitation and evaporation in the Lake Qinghai catchment. In addition, changes of the lake level in the future are simulated according to climate warming scenarios from the IPCC report. The simulated results suggest that the lake level could rise again in the following decades due to the increased precipitation under the climate warming conditions, which is already a trend in the lake level observation data.
\end{abstract}

\section{Keywords}

Hydrochemical Process, Salinity Spatial Distribution and Temporal Variation, Lake 
Level Changes, Lake Qinghai

\section{Introduction}

Most lakes on the Tibetan plateau are endorheic, which means that lake level changes directly reflect the variation of water balance in the catchment and the water cycling process could be recorded by the water chemistry of the lake. Obviously, researches of hydro-chemistry of the lake can be significant, as it reflects the environmental conditions of salt material accumulation or dilution in the lake and the catchment environment around the lake. Therefore, the chemical composition of the lake water provides reliable evidences for modern sedimentary processes in the lake. Many investigations have been performed to study the lake hydrochemistry in the lake e.g. [1]-[8]. Most previous work has clearly focused on the spatial distribution of the water chemistry, the geochemical whereas systematic clarification of hydro-chemical characteristics from temporal and spatial scales is reported less frequently.

As the largest inland saline lake in China, Lake Qinghai is very sensitive to climatic fluctuations and has become a hot topic of research worldwide [9]-[14]. Influenced by climate warming, the water level has fallen dramatically and reduced in area since the beginning of the twentieth century [15] [16] [17], which has led to a series of ecologi$\mathrm{cal} /$ environmental problems such as increasing salinity, deterioration of water quality, loss of grazing grassland around the lake, and desertification in the beach area (Photo 1). Therefore, research on the hydrochemistry of Lake Qinghai is important not only for the elucidation of modern environmental change, but also a significant reference to clarify the formation and evolution of saline lakes on Qinghai-Tibetan Plateau. Many works have been done in the surface and groundwater in the Lake Qinghai catchment, which are useful for the evolution of lake water chemistry [18] [19]. Based on our field investigation and the data from the literature, this paper systematically illustrates the major chemical composition in Lake Qinghai and its controlling mechanisms, mainly
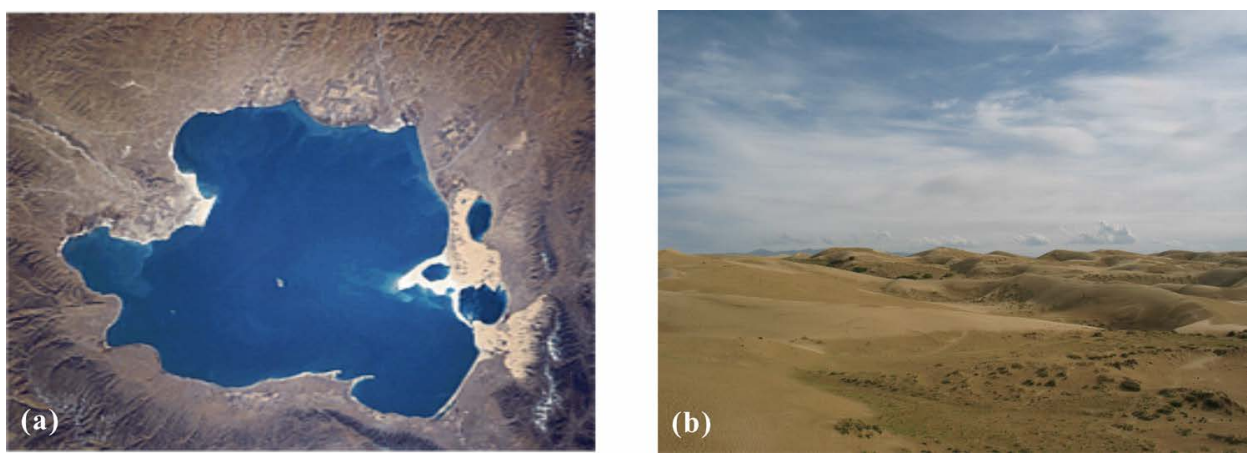

Photo 1. (a) A satellite image of Lake Qinghai, which shows lake shrinkage status in 2005 and some separation of small lakes from the mother lake (northeast part); (b) Large sand dunes have been formed on the northeast bank area by northwest wind blowing sand sediments from a dried lake bed. 
focusing on temporal and spatial variations of hydrochemistry, and predicts which could provide fundamental data for the study of lake sedimentary processes.

\section{Study Area}

Lake Qinghai is situated in the northeastern edge of the Qinghai-Tibetan Plateau, between $36^{\circ} 32 \mathrm{~N}-37^{\circ} 15 \mathrm{~N}$ and $99^{\circ} 36 \mathrm{E}-100^{\circ} 47 \mathrm{E}$ (Figure 1). Its catchment area is approximately $29,660 \mathrm{~km}^{2}$ and the majority is located in the Qilian Mountains in the north and west sides. The lake is $106 \mathrm{~km}$ long from east to west and $62 \mathrm{~km}$ wide from north to south, with a surface area of $4260 \mathrm{~km}^{2}$, and a water surface elevation of $3193 \mathrm{~m}$ a.s.l [20]. The average water depth is $19.15 \mathrm{~m}$ with a maximum depth of $28.7 \mathrm{~m}$ (Measured in August, 2008). Water supply of the lake is mainly dependent the surface runoff and precipitation recharge in the catchment. More than 50 streams flow into the lake, but most are intermittent. Buha River is a longest and largest of the streams, with a discharge volume equal to almost half of the total runoff in the catchment.

Climate in the catchment is cold and semi-arid, influenced by three air masses: East Asian monsoon, Indian monsoon and westerly atmospheric flow [21]. The average annual temperature ranges from -1.3 to $0.5^{\circ} \mathrm{C}$ and the mean annual precipitation varies from 250 to $360 \mathrm{~mm}$, with a coefficient of variance $\left(C_{V}\right)$ of $0.15-0.30$ and more than $85 \%$ of the rainfall between May and September, while the average annual evaporation is up to $800-1100 \mathrm{~mm}$ with a coefficient of variance $\left(C_{V}\right)$ of $0.10-0.15$ and more than

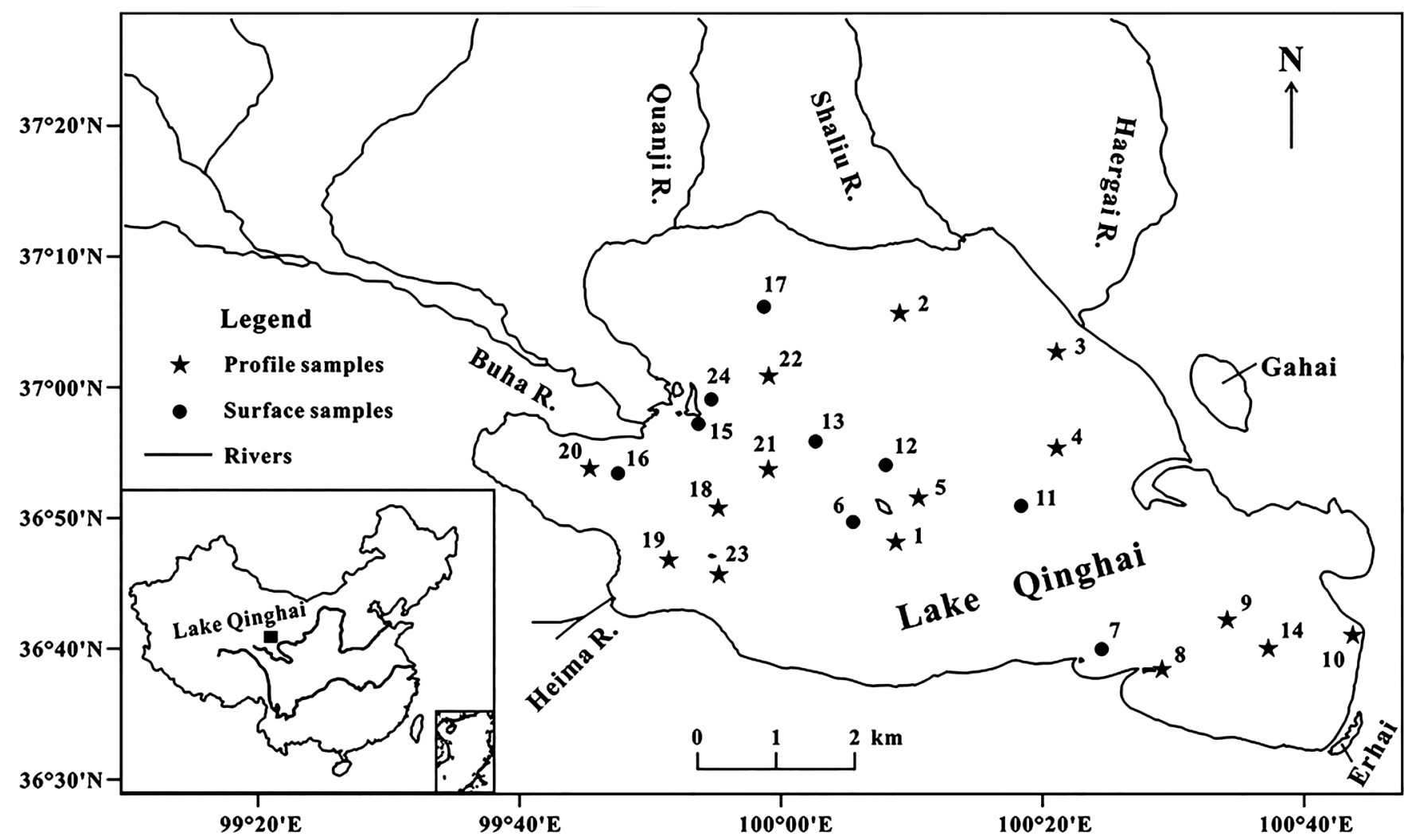

Figure 1. Map showing the location of Lake Qinghai and the distribution of sampling sites in August of 2008. 
$65 \%$ occurring between June and September [11]. The vegetation is dominated by grasses, montane shrub and alpine meadow in the catchment. There are virtually no forests in the basin, only a limited area of desert, and some irrigated farmland to the north and northeast of the lake. The $\mathrm{pH}$ value of the water ranges from 8.9 to 9.5 , and the average salinity is approximately $15.6 \mathrm{~g} / \mathrm{L}$ with a water type of Chloride salts sodium group II [20].

\section{Sampling and Analysis}

Lake hydrochemistry investigation was performed in the summer of 2008. Twenty-four water samples were collected at 24 different sites that covered the whole lake area (Figure 1 , sample numbered Num-01 - Num-24, respectively), including 15 water column samples (at 2 m depth intervals) numbered Num-01, Num-02, Num-03, Num-04, Num-05, Num-08, Num-09, Num-10, Num-14, Num-18, Num-19, Num-20, Num-21, Num-22 and Num-23, and nine surface water samples at the different parts of the lake.

The concentration of bicarbonate was measured using hydrochloric acid titration in the field. All water samples were filtered through $0.45 \mu \mathrm{m}$ membrane filters, and then collected and sealed in acid-washed $100 \mathrm{ml}$ polyethylene plastic bottles. Samples designated for cation analysis were acidified $(\mathrm{pH}<2)$ with a few drops of $1 \mathrm{M}$ hydrochloric acid, and then sealed in a dark environment. Samples used for anions analysis was also stored in the dark. The major cations $\left(\mathrm{Na}^{+}, \mathrm{Mg}^{2+}, \mathrm{K}^{+}\right.$and $\left.\mathrm{Ca}^{2+}\right)$ of the lake were determined by AAS (atomic absorption spectroscopy) and main anions $\left(\mathrm{Cl}^{-}, \mathrm{SO}_{4}^{2-}, \mathrm{CO}_{3}^{2-}\right.$ and $\mathrm{HCO}_{3}^{-}$) were measured with ion chromatography (ICS-2500). Experiments were completed at the State Kay Laboratory of Cryospheric Science, Cold and Arid Regions Environmental and Engineering Research Institute, Chinese Academy of Sciences. The uncertainties are less than $5 \%$.

\section{Results and Discussion}

\subsection{Major Chemical Composition of the Lake Water}

Major ions are composed of $\mathrm{Na}^{+}, \mathrm{K}^{+}, \mathrm{Ca}^{2+}, \mathrm{Mg}^{2+}, \mathrm{CO}_{3}^{2-}, \mathrm{HCO}_{3}^{-}, \mathrm{Cl}^{-}$and $\mathrm{SO}_{4}^{2-}$. There are significant variances in the proportion of major ion content at different sites based on salinity and geological background differences. As seen in Table 1 and Figure 2, $\mathrm{SO}_{4}^{2-}$ is the dominant cation in the lake. The concentration ranges from 4284.3 to $4348.4 \mathrm{mg} / \mathrm{L}$ with an average of $4308.2 \mathrm{mg} / \mathrm{L}$, which is comprises approximately $80.1 \%$ of total cations. $\mathrm{Mg}^{2+}$ concentration varies from 765.105 to $799.0 \mathrm{mg} / \mathrm{L}$, with an average of $790.1 \mathrm{mg} / \mathrm{L}$ and comprises approximately $14.7 \%$. The mean concentrations of $\mathrm{K}^{+}$and $\mathrm{Ca}^{2+}$ are 271.6 and $12.0 \mathrm{mg} / \mathrm{L}$ and comprising approximately $5.1 \%$ and $0.2 \%$ of total cations, respectively. The anions are dominated by $\mathrm{Cl}^{-}$, which has a concentration varying between 6169.9 and $6282.1 \mathrm{mg} / \mathrm{L}$ (mean of $6179.3 \mathrm{mg} / \mathrm{L}$ ), and comprise $60.6 \%$ of the total anions. The content of $\mathrm{SO}_{4}^{2-}$ ranges from 2177.3 to $2622.8 \mathrm{mg} / \mathrm{L}$, with mean concentration of $2419.4 \mathrm{mg} / \mathrm{L}$ and approximately $23.7 \%$ of the total anion content. The average content of the dissolved inorganic carbon (including $\mathrm{CO}_{3}^{2-}$ and $\mathrm{HCO}_{3}^{-}$) is 
Table 1. Major chemical compositions of the surface water in Lake Qinghai (mg/L).

\begin{tabular}{cccccccccc}
\hline & $\mathrm{Na}^{+}$ & $\mathrm{K}^{+}$ & $\mathrm{Mg}^{2+}$ & $\mathrm{Ca}^{2+}$ & $\mathrm{Cl}^{-}$ & $\mathrm{SO}_{4}^{2-}$ & $\mathrm{HCO}_{3}^{-}$ & $\mathrm{CO}_{3}^{2-}$ & Salinity \\
\hline Max & 4348.40 & 272.71 & 799.02 & 12.31 & 6282.08 & 2622.75 & 2183.45 & 396.36 & 16151.61 \\
Min & 4284.30 & 268.67 & 765.05 & 11.17 & 6169.90 & 2177.34 & 996.55 & 220.20 & 15292.20 \\
Mean & 4308.20 & 271.53 & 790.13 & 12.01 & 6179.25 & 2419.48 & 1345.53 & 282.76 & 15585.32 \\
\hline
\end{tabular}

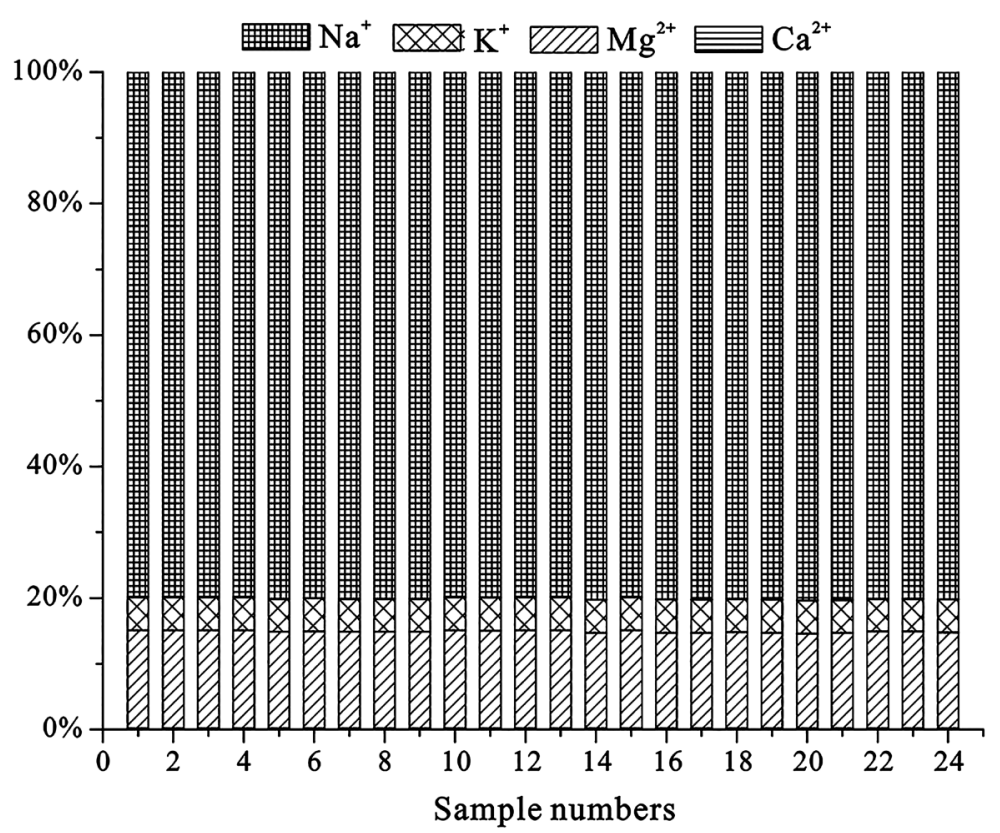

(a)

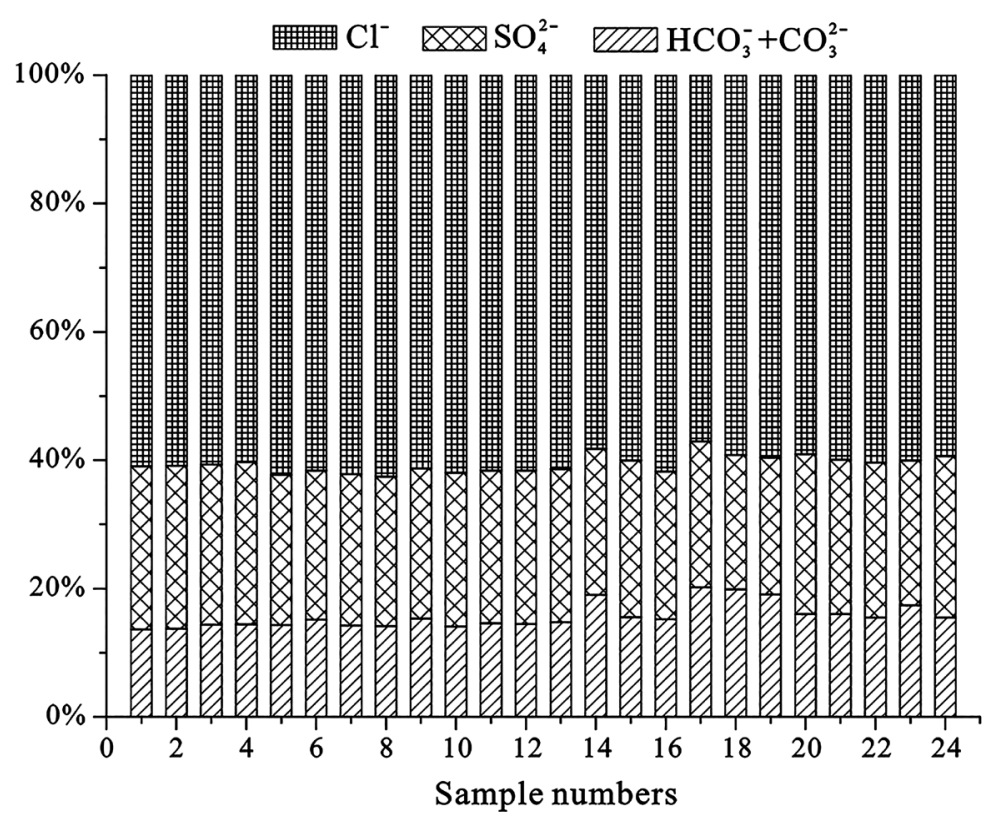

(b)

Figure 2. Percentage of the major cations/total cation concentration (a) and the major anions/ total anion concentration (b) for water samples from Lake Qinghai. 
$1512 \mathrm{mg} / \mathrm{L}$, and comprises approximately $15.7 \%$ of total anions. Characteristic coefficients of the chemical composition of the lake water are as follows: the ratio of $\mathrm{Na}^{+} / \mathrm{K}^{+}$ is $15.87, \mathrm{Mg}^{2+} / \mathrm{K}^{+}$is $2.91, \mathrm{Mg}^{2+} / \mathrm{Ca}^{2+}$ is $65.8, \mathrm{Cl}^{-} / \sum$ salinity is $0.4, \mathrm{SO}_{4}^{2-} / \sum$ salinity is 0.16 , coefficient of sylvite $\left(\mathrm{K}^{+} / \sum\right.$ salinity $\left.^{\star} 100\right)$ is 1.7 and the coefficient of alkalinity $\left(\left(\mathrm{HCO}_{3}^{-}+\mathrm{CO}_{3}^{2-}\right) / \sum\right.$ salinity $\left.{ }^{\star} 100\right)$ is 10.3 . The salinity ranges from 15292.2 to 16151.6 $\mathrm{mg} / \mathrm{L}$ with an average of $15585.3 \mathrm{mg} / \mathrm{L}$. According to O.A. Arliekin's classification (1960) [22], the hydrochemistry type of Lake Qinghai is $\mathrm{Cl}^{-}-\mathrm{Na}^{+}$, which is a common characteristic of salt lakes.

Concentrations of $\mathrm{SO}_{4}^{2-}$ and $\mathrm{K}^{+}$in Lake Qinghai are both quite similar to those in ocean water (Figure 3(a)), whereas other ion concentrations, particular $\mathrm{Ca}^{2+}$ are less than those of ocean water. Furthermore, there are some differences in characteristic coefficients between the lake water and ocean water (Figure 3(b)). The value of $\mathrm{Mg}^{2+} / \mathrm{Ca}^{2+}$ and the coefficient of alkalinity are both significantly higher in Qinghai Lake than in ocean water, probably implying that abundant calcite and aragonite deposits present in Lake Qinghai and that $\mathrm{CaCO}_{3}$ displays a relative saturation.

\subsection{Mechanisms Controlling the Lake Hydrochemistry}

To visualize comparison features of chemical compositions of surface water, Gibbs (1970) [24] proposed the boomerang envelope model to describe the dynamics of chemical compositions of surface water and classified the controlling factors to three types, namely atmospheric precipitation, rock weathering and evaporation/crystallization (Figure 4(a)). Generally, water dominated by $\mathrm{Na}^{+}$and $\mathrm{Cl}^{-}$mainly originates from rainfall and rock weathering and has a high value of $\mathrm{Ca}^{2+}$ and $\mathrm{HCO}_{3}^{-}$. The evaporation/ crystallization dominated water is also characterized with high $\mathrm{Na}^{+}$and $\mathrm{Cl}^{-}$concentrations. The weight ratio of $\mathrm{Na}^{+} /\left(\mathrm{Na}^{+}+\mathrm{Ca}^{2+}\right)$ or $\mathrm{Cl}^{-} /\left(\mathrm{Cl}^{-}+\mathrm{HCO}_{3}^{-}\right)$situates on the $\mathrm{x}$-axis (Figure 4(b) and Figure 4(c)) and the variation of the total dissolved salts (TDS) lies on the y-axis. For increasing $\mathrm{Na}^{+} /\left(\mathrm{Na}^{+}+\mathrm{Ca}^{2+}\right)$ or $\mathrm{Cl}^{-} /\left(\mathrm{Cl}^{-}+\mathrm{HCO}_{3}^{-}\right)$with declining TDS and a descending limb, Gibbs suggested that atmospheric precipitation is the most important factor in controlling hydrochemistry. However, for increasing $\mathrm{Na}^{+} /\left(\mathrm{Na}^{+}+\right.$ $\left.\mathrm{Ca}^{2+}\right)$ or $\mathrm{Cl}^{-} /\left(\mathrm{Cl}^{-}+\mathrm{HCO}_{3}^{-}\right)$with inclining TDS and an ascending limb, Gibbs thought that evaporation/crystallization is the principal control factor. For our study, data of the Lake Qinghai fall within the right-upper Gibbs boomerang envelope model with high ratios of $\mathrm{Na}^{+} /\left(\mathrm{Na}^{+}+\mathrm{Ca}^{2+}\right)$ and $\mathrm{Cl}^{-} /\left(\mathrm{Cl}^{-}+\mathrm{HCO}_{3}^{-}\right)$, indicating that the chemical composition of the lake water are similar to ocean water, dominated by evaporation/crystallization (Figure 4(b) and Figure 4(c)).

In Figure 5, the relationship between $\mathrm{Na}^{+}+\mathrm{K}^{+}$and $\mathrm{Cl}^{-}, \mathrm{Ca}^{2+}+\mathrm{Mg}^{2+}$ and $\mathrm{HCO}_{3}^{-}$of the Qinghai Lake water has been shown. It is clear that the values of $\mathrm{Na}^{+}+\mathrm{K}^{+}$and $\mathrm{Cl}^{-}$ in the Lake Qinghai water are close to the 1:1 equilibration line, whereas $\mathrm{Ca}^{2+}+\mathrm{Mg}^{2+}$ and $\mathrm{HCO}_{3}^{-}$deviate from the 1:1 line. In general, $\mathrm{Na}^{+}-\mathrm{K}^{+}$derive from evaporites and weathering products of silicates, while $\mathrm{Ca}^{2+}-\mathrm{Mg}^{2+}$ originate from carbonates, evaporates and silicates. $\mathrm{HCO}_{3}^{-}$is supplied by dissolution weathering of carbonate, whereas $\mathrm{Cl}^{-}$is generally derived from dissolution of evaporites [25] [26]. Therefore, the two relationship 

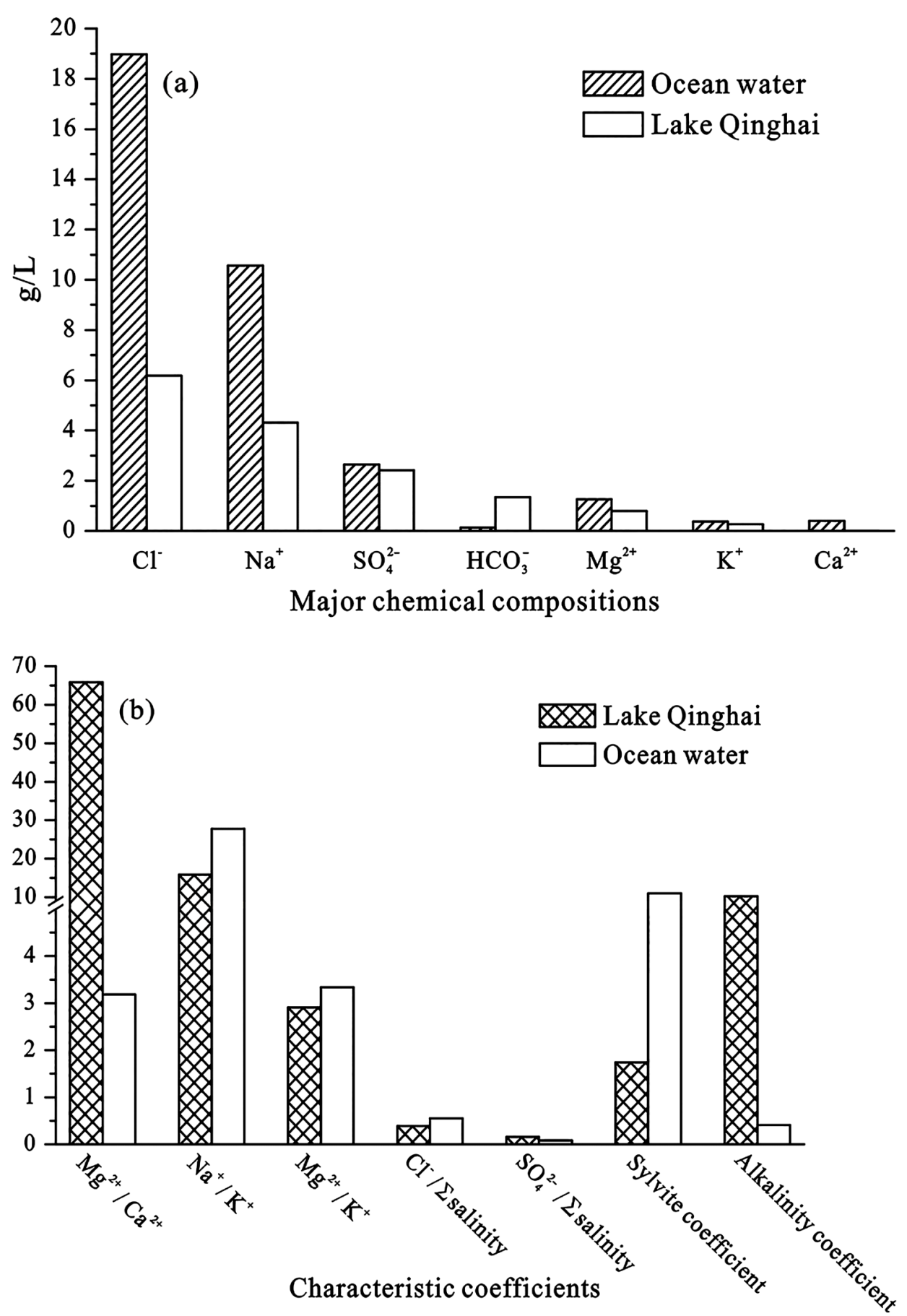

Figure 3. Comparison of chemical composition: (a) Characteristic coefficients, (b) Differences between Qinghai Lake water and ocean water. Note that data of Lake Qinghai originated from the mean value of the sampling sites in 2008 and data of ocean water refers to the research work by Sun et al. (1991) [23].

lines indicate that evaporation play an essential role in controlling the hydrochemistry to a certain extent. It also implies that the human activities have a weak impact on water chemistry in Lake Qinghai. 

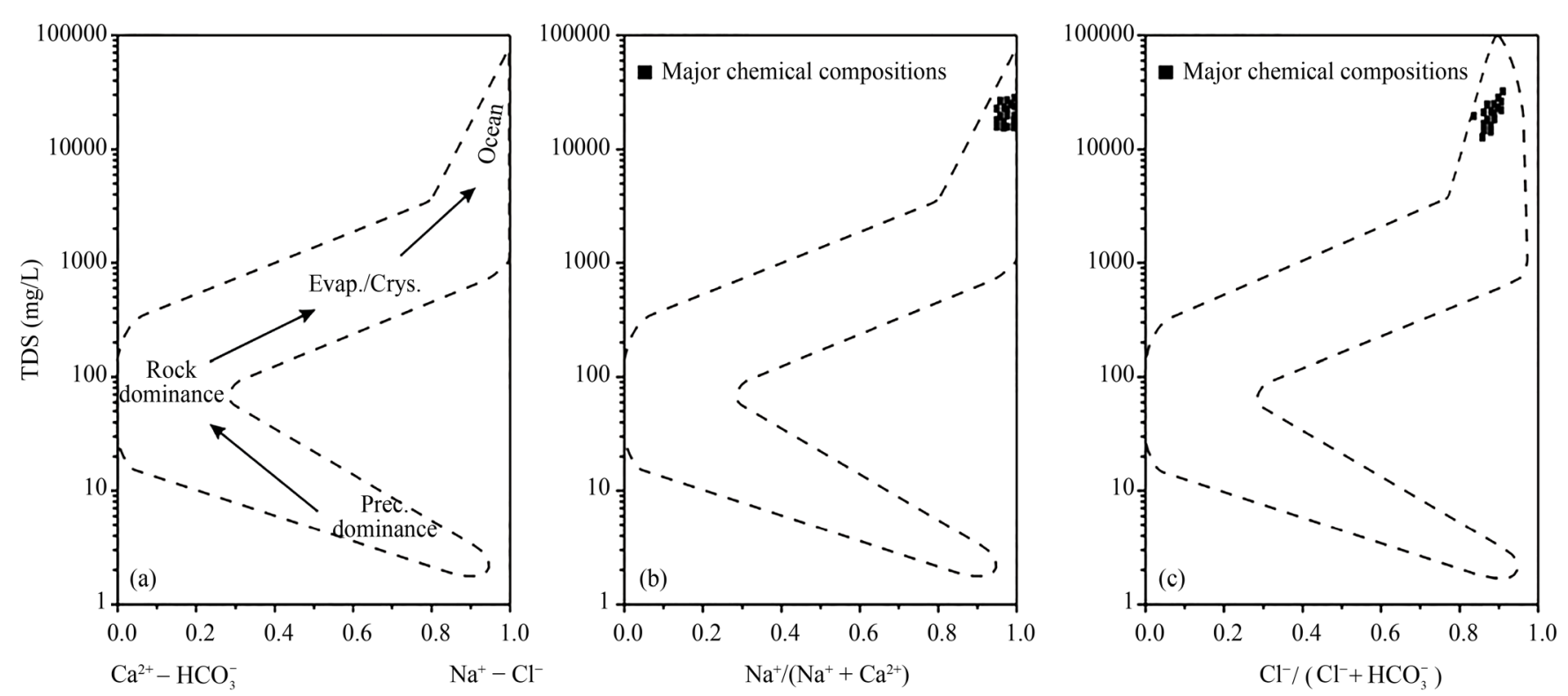

Figure 4. Plots of the major chemical compositions within the Gibbs boomerang envelope for waters in Lake Qinghai. (a), (b) and (c) show major cations and anions of the lake water in the Gibbs model. Note that TDS is calculated by the sum of sodium, potassium, calcium, magnesium, carbonate, bicarbonate, chloride and sulphate concentrations, and from which half of the bicarbonate concentration is subtracted.
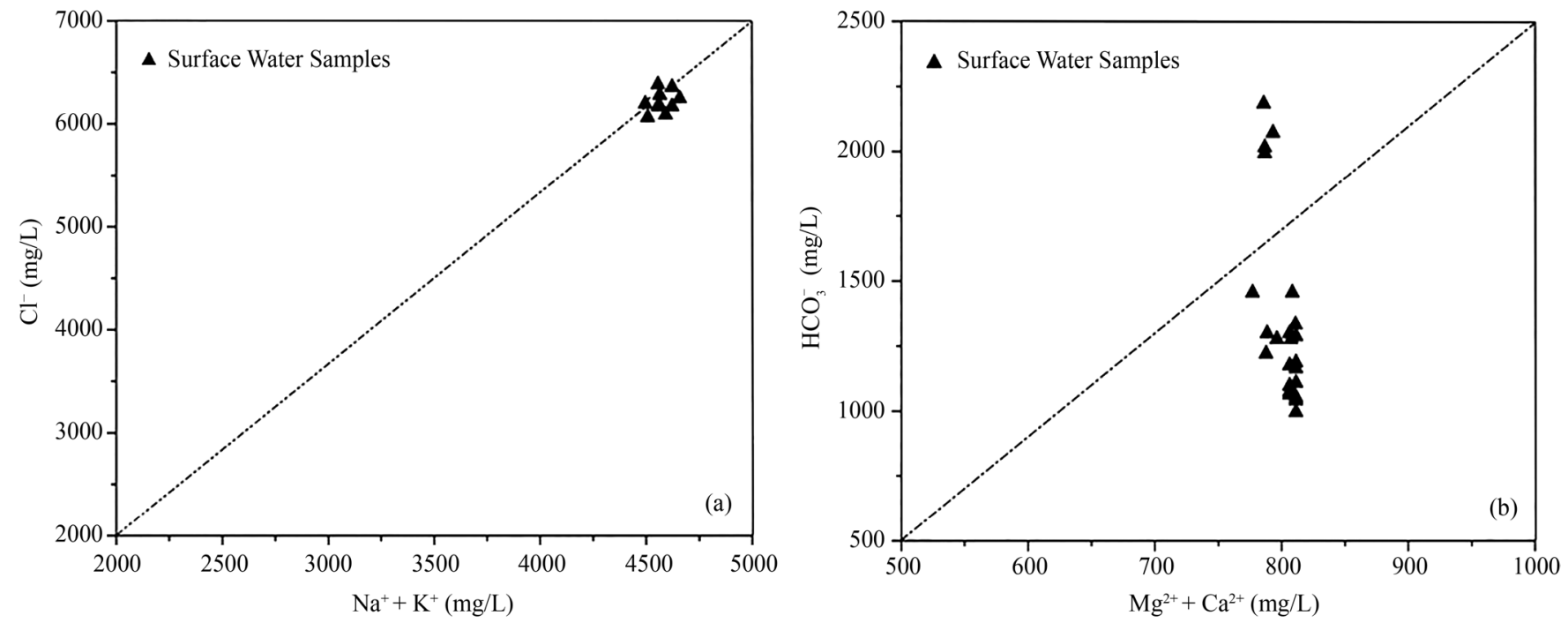

Figure 5. Relationship between $\mathrm{Na}^{+}+\mathrm{K}^{+}$and $\mathrm{Cl}^{-}(\mathrm{a}), \mathrm{Ca}^{2+}+\mathrm{Mg}^{2+}$ and $\mathrm{HCO}_{3}^{-}$(b).

\subsection{Spatial Distribution of Chemical Composition of the Lake}

\subsubsection{Horizontal Distribution of Chemical Composition of Surface Water}

Many factors such as lake basin morphology, hydrodynamic characteristics of the lake, catchment conditions around the lake, chemical properties of inflows could probably impact the horizontal distribution of the lake chemical composition. Changes in surface water chemical composition at 24 sampling sites in Lake Qinghai are listed in Table 2. Major ion concentrations and salinity have no obvious spatial variation in the surface 
Table 2. Changes in chemical composition of the surface water in Lake Qinghai (mg/L).

\begin{tabular}{cccccccccc}
\hline & $\mathrm{Na}^{+}$ & $\mathrm{K}^{+}$ & $\mathrm{Mg}^{2+}$ & $\mathrm{Ca}^{2+}$ & $\mathrm{Cl}^{-}$ & $\mathrm{SO}_{4}^{2-}$ & $\mathrm{HCO}_{3}^{-}$ & $\mathrm{CO}_{3}^{2-}$ & Salinity \\
\hline Mean & 4308.20 & 271.53 & 790.13 & 12.01 & 6179.25 & 2419.48 & 1345.53 & 282.76 & 15585.32 \\
\multirow{2}{*}{ STDEV } & 28.56 & 1.45 & 10.75 & 0.43 & 27.01 & 123.02 & 351.68 & 125.53 & 215.17 \\
\hline
\end{tabular}

water, with a standard deviation (STDEV) of $0.43-351.7 \mathrm{mg} / \mathrm{L}$, which may be related to the supply of water systems in the vicinity of Lake Qinghai throughout the year and lake currents generated from frequent wind actions.

\subsubsection{Vertical Variation in Chemical Composition of the Lake}

The variation of chemical composition in vertical water profiles is likely influenced by the lake basin morphology, water depth and hydrodynamic characteristics. Table 3 lists the vertical variation of major ions contents and salinities of 15 water profiles collected in August, 2008. In general, the concentrations of carbonate and bicarbonate anions have more obvious changes in the vertical water profiles than other main ions, with standard deviation (STDEV) of 23.2 - 93.6 and 54.1 - $312.9 \mathrm{mg} / \mathrm{L}$, respectively. Changes of $\mathrm{Na}^{+}, \mathrm{K}^{+}, \mathrm{Cl}^{-}$and $\mathrm{SO}_{4}^{2-}$ are small and almost equal with depth in every profile. The salinity fluctuations with water depth at different sites of the lake have a STDEV range from 19.8 to $303.8 \mathrm{mg} / \mathrm{L}$ in 15 water profiles and can easily be divided into three types of change trends. (1) The salinity of surface layer is relatively high in the water profiles of Num-02, Num-10, Num-14 and Num-21 (Figure 6(a)), which is probably because these profiles are nearby the lakeshore and bay, resulting in strong evaporation and relative difficulty of transporting surface soluble substances to the bottom. Additionally, there is no recharge of freshwater directly into the above sampling sites. (2) The salinity of bottom water is comparatively high in the water profiles of Num-01, Num-03, Num-05, Num-22 and Num-23 (Figure 6(b)). These sites are usually located in the centre parts of the lake with excessive accumulation of soluble salts in the bottom water. Moreover, large river inflow (e.g., Buha R., Haergai R. and Heima R.) would dilute chemical substances of the surface water layer to some extent. (3) The salinity has no obvious trend in vertical direction at other collected sites (Figure 6(c)).

\subsection{Temporal Variation of Hydrochemistry}

\subsubsection{Variation and Impact Factors of Hydrochemistry from 1960 to 2008}

The increased salinity was accompanied by an overall downward trend in water level of the Qinghai Lake during the stage from the 1960s to the 2000s (Figure 7(a), Figure 7(b)). The salinity was $12.5 \mathrm{~g} / \mathrm{L}$ in 1961 , and it increased to $16.1 \mathrm{~g} / \mathrm{L}$ in 2001 , which was an increase of nearly $4 \mathrm{~g} / \mathrm{L}$ in 40 years with an average rate of $0.09 \mathrm{~g} / \mathrm{L} \cdot \mathrm{yr}^{-1}$. The fastest growth occurred in the 1990s. Meanwhile, lake level declined sharply from the 1960s to the $2000 \mathrm{~s}$ and decreased by $3.57 \mathrm{~m}$ in total, with an average rate of $-0.08 \mathrm{~m} / \mathrm{yr}$. In the summer of 2008 , the salinity decreased to $15.9 \mathrm{~g} / \mathrm{L}$, which was lower than those in the early 2000s. During the period of 1956-1988, the water level fell $3.2 \mathrm{~m}$ at a rate of 0.09 $\mathrm{m} / \mathrm{yr}$, and the lake level decreased by $0.7 \mathrm{~m}$, with mean rate of $0.06 \mathrm{~m} / \mathrm{yr}$ in 1989-2000. 
Table 3. Vertical variation of chemical composition in Lake Qinghai (mg/L).

\begin{tabular}{|c|c|c|c|c|c|c|c|c|c|c|}
\hline Numbers & Items & $\mathrm{Na}^{+}$ & $\mathrm{K}^{+}$ & $\mathrm{Mg}^{2+}$ & $\mathrm{Ca}^{2+}$ & $\mathrm{Cl}^{-}$ & $\mathrm{SO}_{4}^{2-}$ & $\mathrm{HCO}_{3}^{-}$ & $\mathrm{CO}_{3}^{2-}$ & Salinity \\
\hline \multirow{2}{*}{ Num-01 } & Mean & 4303.63 & 272.10 & 799.73 & 10.84 & 6230.00 & 2612.38 & 1054.13 & 352.32 & 15635.13 \\
\hline & STDEV & 24.47 & 0 & 1.52 & 2.04 & 46.48 & 55.33 & 69.56 & 37.40 & 88.78 \\
\hline \multirow{2}{*}{ Num-02 } & Mean & 4295.42 & 271.54 & 797.60 & 12.01 & 6173.91 & 2517.51 & 1104.52 & 324.80 & 15497.30 \\
\hline & STDEV & 15.36 & 1.42 & 2.33 & 1.10 & 14.99 & 87.88 & 87.68 & 34.75 & 115.39 \\
\hline \multirow{2}{*}{ Num-03 } & Mean & 4297.07 & 272.10 & 798.52 & 12.31 & 6175.51 & 2576.30 & 1135.39 & 315.99 & 15583.17 \\
\hline & STDEV & 18.17 & 0 & 1.05 & 0 & 17.74 & 36.15 & 55.66 & 23.24 & 19.82 \\
\hline \multirow{2}{*}{ Num-04 } & Mean & 4306.99 & 272.10 & 796.98 & 12.31 & 6175.00 & 2572.60 & 1189.95 & 299.27 & 15625.20 \\
\hline & STDEV & 26.84 & 0 & 2.18 & 0 & 16.91 & 40.33 & 70.66 & 34.05 & 45.57 \\
\hline \multirow{2}{*}{ Num-05 } & Mean & 4348.40 & 272.71 & 795.60 & 12.31 & 6218.98 & 2386.95 & 1130.91 & 309.66 & 15475.51 \\
\hline & STDEV & 0 & 0 & 1.85 & 0 & 19.83 & 82.31 & 58.95 & 29.68 & 103.68 \\
\hline \multirow{2}{*}{ Num-08 } & Mean & 4348.40 & 272.71 & 794.04 & 12.31 & 6169.90 & 2331.92 & 1150.82 & 291.15 & 15371.25 \\
\hline & STDEV & 0 & 0 & 0 & 0 & 0 & 47.12 & 69.95 & 30.21 & 56.62 \\
\hline \multirow{2}{*}{ Num-09 } & Mean & 4295.30 & 272.71 & 796.15 & 12.31 & 6169.90 & 2372.47 & 1198.96 & 281.18 & 15398.97 \\
\hline & STDEV & 15.95 & 0 & 2.24 & 0 & 0 & 41.40 & 54.18 & 24.87 & 58.84 \\
\hline \multirow{2}{*}{ Num-10 } & Mean & 4290.88 & 272.71 & 794.66 & 12.31 & 6169.90 & 2479.24 & 1084.73 & 334.43 & 15438.85 \\
\hline & STDEV & 0 & 0 & 1.76 & 0 & 0 & 101.73 & 65.68 & 28.79 & 133.05 \\
\hline \multirow{2}{*}{ Num-14 } & Mean & 4284.30 & 270.43 & 776.60 & 11.72 & 6187.16 & 2473.58 & 2091.29 & - & 16095.07 \\
\hline & STDEV & 0 & 0 & 6.18 & 0.38 & 26.94 & 136.19 & 53.92 & - & 140.28 \\
\hline \multirow{3}{*}{ Num-18 } & Mean & 4284.30 & 270.43 & 779.02 & 11.72 & 6195.79 & 2361.77 & 1825.16 & - & 15728.18 \\
\hline & & & & & & & & & & \\
\hline & STDEV & 0 & 0 & 4.33 & 0.38 & 29.10 & 176.94 & 312.87 & - & 303.84 \\
\hline \multirow{2}{*}{ Num-19 } & Mean & 4284.30 & 270.43 & 774.74 & 11.96 & 6197.95 & 2407.07 & 1603.43 & 184.02 & 15678.70 \\
\hline & STDFY & 0 & 0 & 0 & 0 & & 140 & 0 10 & 0257 & 170 \\
\hline \multirow{3}{*}{ Num-20 } & Mean & 4284.30 & 270.43 & 771.28 & 11.85 & 6169.90 & 2514.58 & 1439.63 & 228.87 & 15690.83 \\
\hline & & & & & & & & & & \\
\hline & STDEV & 0 & 0 & 5.20 & 0.30 & 0 & 52.89 & 84.76 & 51.47 & 74.19 \\
\hline \multirow{2}{*}{ Num-21 } & Mean & 4346.14 & 268.67 & 786.70 & 11.88 & 6169.90 & 2394.63 & 1246.09 & 367.83 & 15581.83 \\
\hline & STDEV & 0 & 0 & 7.09 & 0.38 & 0 & 158.00 & 108.33 & 52.49 & 176.16 \\
\hline \multirow{3}{*}{ Num-22 } & Mean & 4346.14 & 268.67 & 789.85 & 12.05 & 6174.71 & 2413.63 & 1311.67 & 334.23 & 15650.95 \\
\hline & & & & & & & & & & \\
\hline & STDEV & 0 & 0 & 6.90 & 0.22 & 17.99 & 108.88 & 116.77 & 37.05 & 111.62 \\
\hline \multirow{3}{*}{ Num-23 } & Mean & 4346.14 & 268.67 & 788.53 & 12.11 & 6215.79 & 2421.45 & 1435.27 & 310.28 & 15789.25 \\
\hline & & & & & & & & & & \\
\hline & STDEV & 0 & 0 & 6.18 & 0 & 22.69 & 159.30 & 128.92 & 64.16 & 185.80 \\
\hline
\end{tabular}



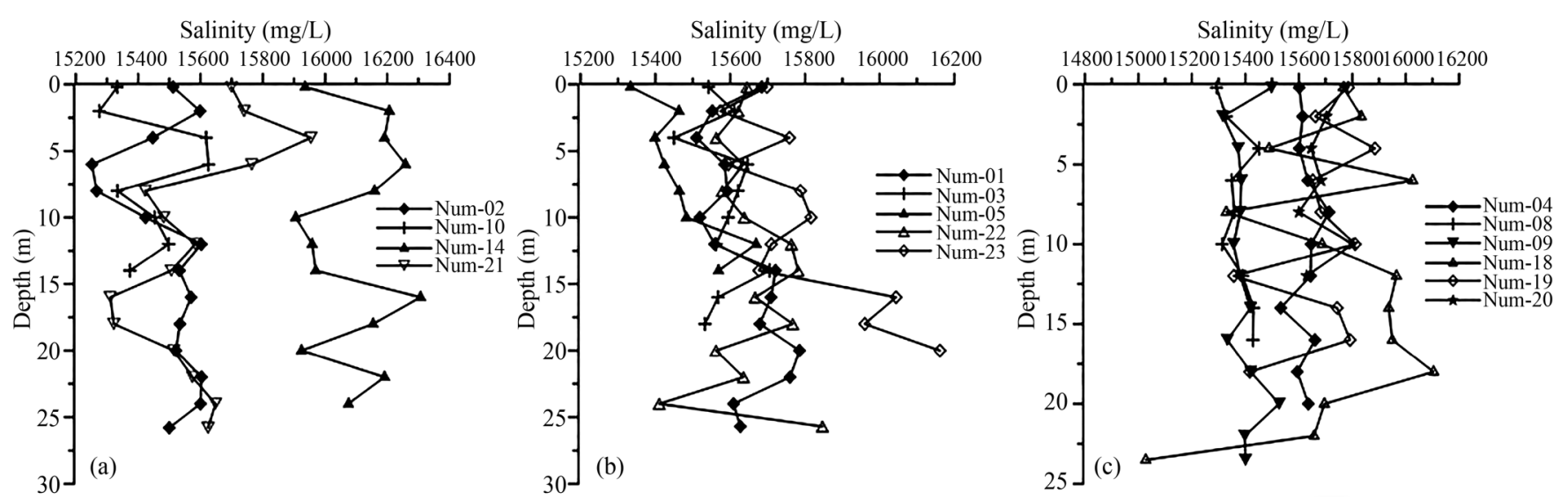

Figure 6. Fluctuation trends of salinity with water depth of 15 profiles in Lake Qinghai: (a) the salinity of the surface water layer is relatively high, (b) the salinity of bottom water layer is comparatively high, and (c) the salinity has no obvious trend in vertical direction.
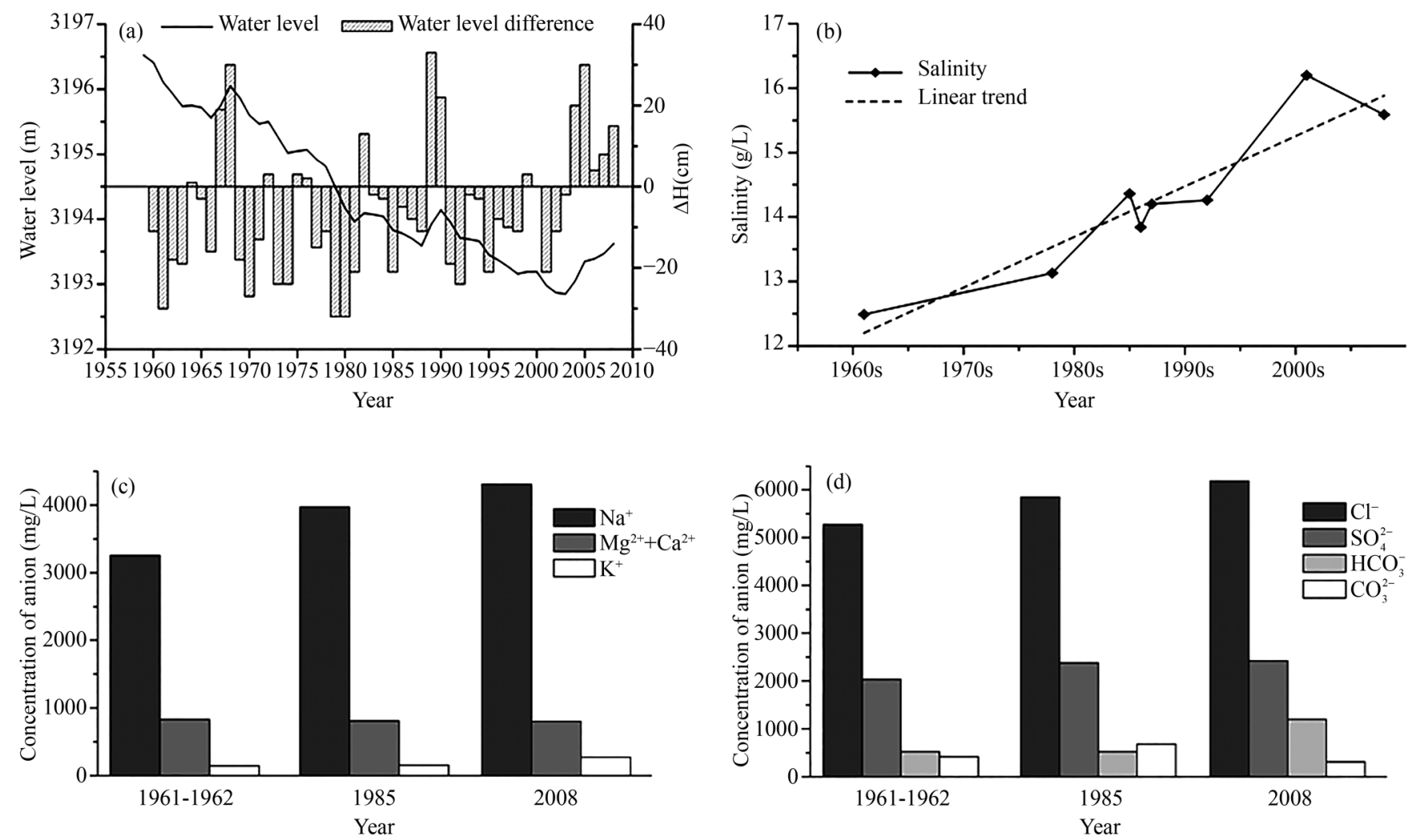

Figure 7. Water level fluctuations of Qinghai Lake from 1960 to 2008 (a); Salinity variations of the Qinghai Lake from 1960s to 2000s (b); Changes in cation (c); Anion concentrations of the Qinghai Lake in 1961-1962, 1985 and 2008 (d). The data sources: Wang and Dou (1998) [20]; Lanzhou Branch, Chinese Academy of Science (1994) [27]; Yi et al. (2010) [28].

However, the lake has increased in the most recent eight years, and has continuously risen nearly $50 \mathrm{~cm}$ from 2005 to 2008, with a reduction in salinity. However, major ion contents of the lake water have not changed obviously due to its large lake hysteresis effect, which means that changes to chemical composition occur slower to some extent than lake level change. 
Figure 7(c) and Figure 7(d) show that almost all of the ion concentrations changed as a result of the water level decline of the past 40 years. $\mathrm{HCO}_{3}^{-}$concentration experienced a large change from $525 \mathrm{mg} / \mathrm{L}$ to $1201 \mathrm{mg} / \mathrm{L}$, suggesting that the alkalinity of the lake gradually increased. The amount of $\mathrm{K}^{+}$and $\mathrm{SO}_{4}^{2-}$ gently increased, whereas $\mathrm{Ca}^{2+}$ and $\mathrm{Mg}^{2+}$ remained unchanged. In addition, the content of $\mathrm{Na}^{+}$and $\mathrm{Cl}^{-}$had a certain degree of increase (1050 and 904, respectively) from 1961 to 2008 . Both $\mathrm{Na}^{+}$and $\mathrm{Cl}^{-}$had been the dominant cation and anion in the Qinghai Lake during the past 40 years, indicating that the water chemistry had been kept in $\mathrm{Cl}^{-}-\mathrm{Na}^{+}$type, dominated by evaporation/crystallization through the entire time period.

Changes in major ion concentrations, salinity and water level observed are closely related to climate factors including temperature, precipitation, evaporation and wind speed in the Qinghai Lake catchment recorded from 1960 to 2008. Correlations can be observed between the annually lake level change and the mean annual precipitation (Figure 8(a)), the annual mean evaporation (Figure 8(b)), the annual mean temperature (Figure 8(c)) and the annual mean wind speed (Figure 8(d)). Results show that the variation of lake level was highly positively correlated to precipitation and negatively to evaporation, with correlation coefficients of 0.81 and -0.72 , respectively. However, correlation coefficients between lake level and temperature, as well as between
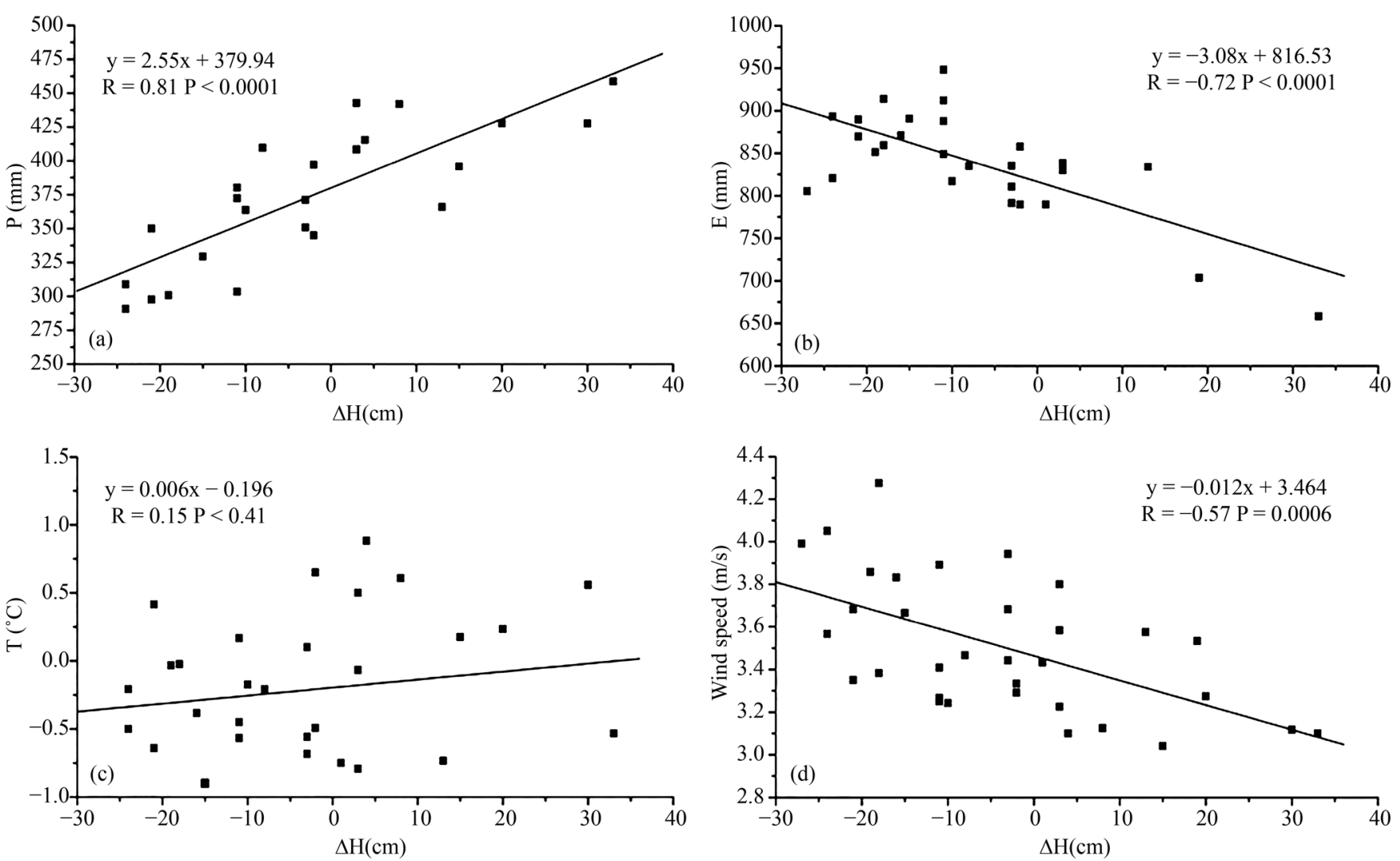

Figure 8. Relationship between annual changes of the lake level $(\Delta \mathrm{H})$ and the mean annual precipitation $(\mathrm{P})$, mean annual mean evaporation (E), mean annual temperature (T), and mean annual wind speed in the catchment of Lake Qinghai from 1960 to 2008 . Note that: $\Delta \mathrm{H}$ data refers to work by Yi et al. (2010) [28]; Data of climate proxies are calculated by meteorological observation data at Gangcha station. 
lake level and wind speed are 0.15 and -0.57 , respectively. This would imply that the water level is mainly influenced by precipitation and evaporation (namely dry or wet climate). Additionally, wind speed could play an important role in evaporation process. However, the variation of lake level had little association with fluctuation of temperature, which would also exert some influence on the evaporation.

As seen in Table 4, temperature had a remarkable warming trend in the 1990s. It was $0.3^{\circ} \mathrm{C}-0.4^{\circ} \mathrm{C}$ higher in the 1970 s than the 1960 s and nearly $1.0^{\circ} \mathrm{C}$ higher in the $1990 \mathrm{~s}$ than the 1960s. In the case of precipitation, obvious fluctuations occurred, with an increasing trend in the 1960s and 1980s and a decreasing trend in the 1970s and 1990s. Precipitation increased gradually in the most recent 10 years at a rate of $20 \mathrm{~mm}$ per year compared with the 1990s. On the whole, mean annual evaporation and wind speed had an overall downward trend during the study period. The water level had an overall downward trend from 1961 to 2005 with the largest decrease in the 1990s due to lower the precipitation in the catchment [29]. The amount of evaporation exceeded the total amount of precipitation and runoff, which resulted in the warming and drying of the climate [30]. In the last 10 years, the lake level has been gradually rising again from an increase in precipitation, implying that the climate is shifting from warm-dry to warmwet.

\subsubsection{Change Trends in Hydrochemistry of Lake Qinghai in the Future}

To understand lake hydrological processes in the future under climate warming conditions, a combined model was created to simulate the lake level changes in the future [31]. The model is composed of the lake level change model (LLCM) and a statistical downscaling model (SDM). The former is a combination of the SWAT Model [32], which is designed to simulate hydrological processes in the catchment and the water balance model (WBM). The latter is derived from the output of SRES A2 scheme from the MPI-OM1 GCM model [33] and in a Grid of ECHAM 5.0 [34] near the Lake Qinghai catchment as the large scale climate information. Climate scenarios for the future 50

Table 4. Inter-annually variations of water level, salinity of the Qinghai Lake and climatic proxies in the catchment.

\begin{tabular}{lccccc}
\hline & $1961-1970$ & $1971-1980$ & $1981-1990$ & $1991-2000$ & $2001-2008$ \\
\hline Mean water level $(\mathrm{m})$ & 3195.81 & 3194.98 & 3193.91 & 3193.46 & 3193.63 \\
Rate of water level changes $(\mathrm{cm} / \mathrm{a})$ & -8.10 & -14.30 & -0.30 & -9.50 & 5.30 \\
Mean salinity $(\mathrm{g} / \mathrm{L})$ & 12.49 & 13.13 & 13.28 & 14.26 & 15.89 \\
Mean precipitation $(\mathrm{mm})$ & 377.04 & 365.13 & 402.11 & 370.93 & 390.43 \\
Mean evaporation $(\mathrm{mm})$ & 829.97 & 888.08 & 794.68 & 842.99 & 815.56 \\
Mean temperature $\left({ }^{\circ} \mathrm{C}\right)$ & -0.81 & -0.48 & -0.39 & -0.07 & 0.46 \\
Mean wind speed $(\mathrm{m} / \mathrm{s})$ & 3.68 & 3.81 & 3.59 & 3.42 & 3.19 \\
Climatic types & cold-dry & cold-dry & cold-wet & warm-dry & warm-wet \\
\hline
\end{tabular}

Data sources: Yi et al. (2010) [28]; Meteorological Observation Station at Gangcha; and Lanzhou Branch Chinese Academy of Science (1994) [27]. 
years (2000-2030) in the catchment of Lake Qinghai are obtained using the Statistical Downscaling Model [35] [36] [37]. Based on established databases from selected data of the meteorology, hydrology, EDM, vegetation, soil features and land use, social characteristics and water demands and so on, the water balance and water level changes of Lake Qinghai in the future were simulated. To facilitate the calculation, the catchment is divided into 62 sub-basin and 155 hydrological response unions (Figure 9). The SWAT model for modeling the hydrological processes in the catchment had been checked by the runoff observation data from 1990 to 2000 with a relation coefficient of 0.95 . The lake water balance model had been checked by observational data of lake level changes from 1981 to 2000 with a relation coefficient of 0.92 . The final simulation result shows that the lake level will display an upward trend in coming years and will reach approximately $3195.4 \mathrm{~m}$ in 2030, with total increases of $2.2 \mathrm{~m}$ compared with $3192.8 \mathrm{~m}$ at present (Figure 10). Accordingly, the increasing trend of the lake level would result in the reduction of major ion concentrations and salinity in the coming decades, which is associated with an increase in precipitation and leads to the enhancement of runoff, the expansion of the lake surface area and the desalination of the lake water. In view of this case, a better ecological environment and richer biodiversity could be expected in Lake Qinghai catchment after years with continuous climate warming predicted by the IPCC. In fact, the lake level has risen gradually since 2005 with precipitation in the catchment increasing annually, as observed by in situ monitoring; these observations provide credibility to the simulations.

\section{Conclusion}

We investigated the hydrochemistry of Lake Qinghai including chemistry and spatial distribution characteristics as well as its evolution. $\mathrm{Na}^{+}$and $\mathrm{Cl}^{-}$were the dominant cations and anions in the lake water, and hydrochemistry type was $\mathrm{Cl}^{-}-\mathrm{Na}^{+}$with an obvious characteristic of a saline lake. For this study, the Gibbs plot illuminated that the dominant mechanisms responsible for controlling chemical composition of the lake
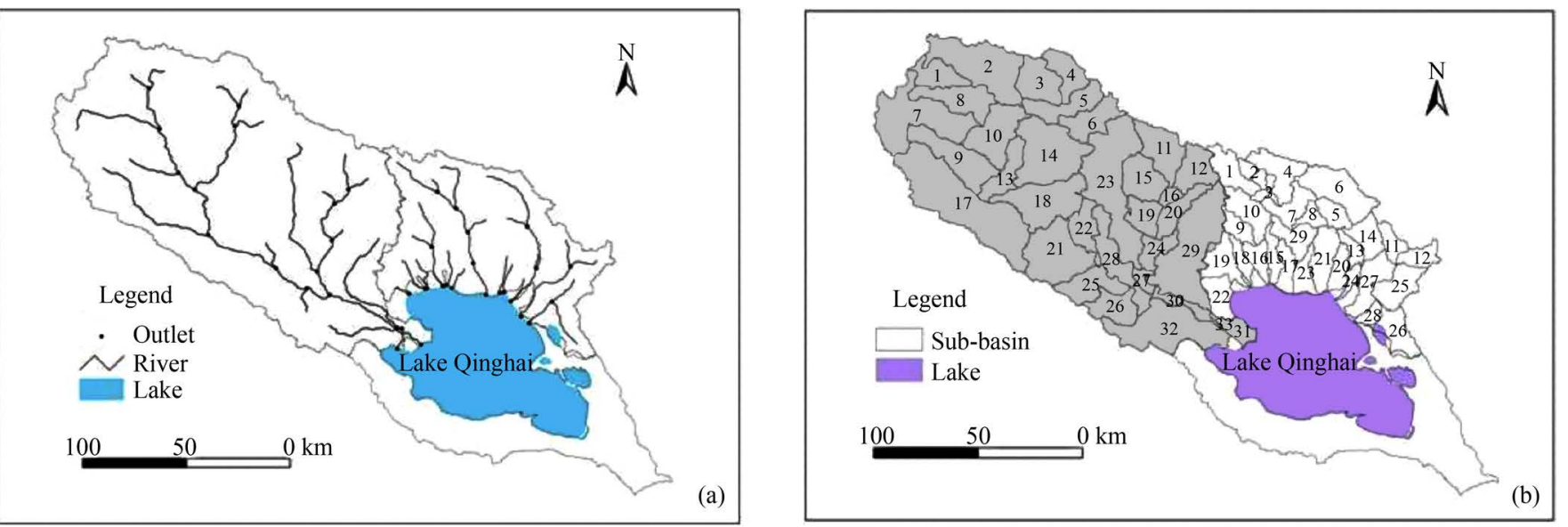

Figure 9. The catchment of Lake Qinghai (a) and the dividing scheme for sub-hydrological units of Lake Qinghai basin (b). (Liu et al., 2007) [31]. 


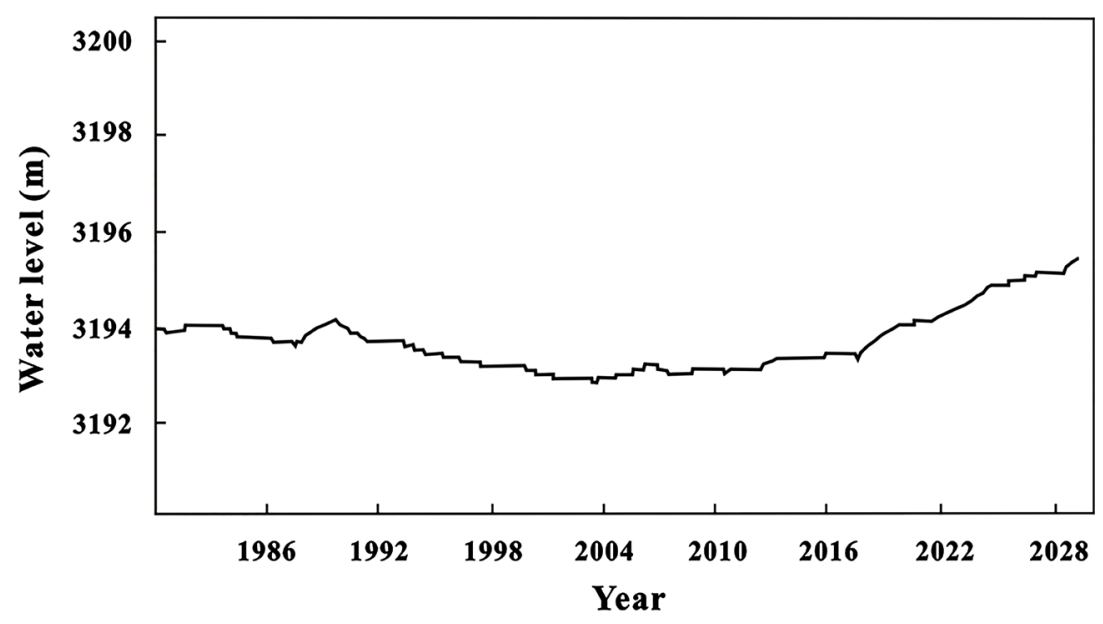

Figure 10. Trends of simulated water level changes of Lake Qinghai in the future (Liu et al., 2007) [31].

water were evaporation/crystallization. The increase of salinity was accompanied by an overall downward trend in water level of Lake Qinghai from the 1960s to 2000s. This might be attributed to the balance of precipitation and evaporation in the catchment. Based on the simulated model, the lake level will rise gradually in the coming decades with precipitation increasing under climate warming scenarios (Liu et al., 2007). This could be benefit to the ecological environment and biodiversity in the catchment.

\section{Acknowledgements}

Many thanks are given to Qinghai Lake National Nature Reserve and Mr. He Yubang and Zhang Hu for kind help in field investigations. The authors are also grateful to the Ministry of Science and Technology for the program financial support (No. 2006FY 110600).

\section{References}

[1] Yang, X.P. (2002) Water Chemistry of the Lakes in the Badain Jaran Desert and Their Holocene Evolution. Quaternary Research, 22, 97-104. (In Chinese)

[2] Andreas, R., Günter, L. and Stephan, K. (2009) Lake Van, Eastern Anatolia, Hydrochemistry and History. Aquatic Geochemistry, 15, 195-222. https://doi.org/10.1007/s10498-008-9049-9

[3] Wang, J.B., Zhu, L.P., Ju, J.T., et al. (2009) Water Chemistry of Eastern Nam Lake Area and Inflowing Rivers in Tibet. Scientia Geographica Sinica, 29, 288-293. (In Chinese)

[4] Zheng, M.P. and Liu, X.F. (2009) Hydrochemistry of Salt Lakes of the Qinghai-Tibet Plateau, China. Aquatic Geochemistry, 15, 293-320. https://doi.org/10.1007/s10498-008-9055-y

[5] Victor, H.C. and Javler, U. (2010) Hydrochemistry of Lakes of the Patagonian Province of Tierra del Fuego (Argentina). Environment Earth Science, 59, 1431-1436. https://doi.org/10.1007/s12665-009-0129-y

[6] Xu, H., Hou, Z.H., An, Z.S., et al. (2010) Major Ion Chemistry of Water in Lake Qinghai Catchments, NE Qinghai-Tibet Plateau, China. Quaternary International, 212, 35-43. 
https://doi.org/10.1016/j.quaint.2008.11.001

[7] Zeng, H.A. and Wu, J.L. (2010) Lake Status of Water Quality and the Changes in Inner Mongolia-Xinjiang Plateau. Journal of Lake Sciences, 22, 882-887. (In Chinese)

[8] Zhu, L.P., Ju, J.T., Wang, Y., et al. (2010) Composition, Spatial Distribution, and Environmental Significance of Water Ions in Pumayum Co Catchment, Southern Tibet. Journal of Geographical Sciences, 20, 109-120. (In Chinese) https://doi.org/10.1007/s11442-010-0109-x

[9] Lister, G.S., Kelts, K., Zao, C.K., et al. (1991) Lake Qinghai, China: Closed-Basin Lake Levels and the Oxygen Isotope Record for Ostracoda since the Latest Pleistocene. Pataeogeography, Palaeoclimatology, Palaecology, 84, 141-162. https://doi.org/10.1016/0031-0182(91)90041-O

[10] Yu, J.Q. and Kelts, K.R. (2002) Abrupt Changes in Climatic Conditions across the LateGlacial/Holocene Transition on the N.E. Tibet-Qinghai Plateau: Evidence from Lake Qinghai, China. Journal of Paleolimnology, 28, 195-206.

https://doi.org/10.1023/A:1021635715857

[11] Shen, J., Liu, X.Q., Wang, S.M. and Ryo, M. (2005) Palaeoclimatic Changes in the Qinghai Lake Area during the Last 18,000 Years. Quaternary International, 136, 131-140. https://doi.org/10.1016/j.quaint.2004.11.014

[12] Xu, H., Hou, Z.H., Ai, L. and Tan, L.C. (2007) Precipitation at Lake Qinghai and Its Relation to Asian Summer Monsoons on Decadal/Interdecadal Scales during the Past 500 Years. Pataeogeography, Palaeoclimatology, Palaecology, 254, 541-549. https://doi.org/10.1016/j.palaeo.2007.07.007

[13] Lu, H.Y., Zhao, C.F., Mason, J., et al. (2010) Holocene Climatic Changes Revealed by Aeolian Deposits from the Qinghai Lake Area (Northeastern Qinghai-Tibetan Plateau) and Possible Forcing Mechanisms. The Holocene, 21, 297-304.

[14] An, Z.S., Colman, S.M., Zhou, W.J., et al. (2012) Interplay between the Westerlies and Asian Monsoon Recorded in Lake Qinghai Sediments since 32 ka. Scientific Reports, 2, Article Number: 619. https://doi.org/10.1038/srep00619

[15] Yang, G.L. and Liu, G.D. (1992) On the Water Level Decline and Its Tendency in Lake Qinghai. Journal of Lake Science, 4, 17-24. (In Chinese) https://doi.org/10.18307/1992.0303

[16] Zhou, L.S. and Wang, Q.C. (1996) Analysis and Forecast for Interannual Variation of the Qinghai Lake's Water Level. Plateau Meteorology, 15, 478-484. (In Chinese)

[17] Liu, X.Y. (2001) Analysis on the Change Trend of Water Level of Qinghai Lake. Arid Zone Research, 18, 58-62. (In Chinese)

[18] Zhang, F., Jin, Z.D., Hu, G., Li, F. and Shi, Y. (2009) Seasonally Chemical Weather and $\mathrm{CO}_{2}$ Consumption Flux of Lake Qinghai River System in the Northeastern Tibetan Plateau. Environment Earth Science, 59, 297-313. https://doi.org/10.1007/s12665-009-0027-3

[19] Xiao, J., Jin, Z.D. and Zhang, F. (2013) Geochemical and Isotopic Characteristics of Shallow Groundwater within the Lake Qinghai Catchment, NE Tibetan Plateau. Quaternary International, 313-314, 62-73. https://doi.org/10.1016/j.quaint.2013.05.033

[20] Wang, S.M. and Dou, H.S. (1998) Lake in China. Science Press, Beijing, 472-473. (In Chinese)

[21] Qin, B.Q. and Huang, Q. (1998) Evaluation of the Climatic Change Impacts on the Inland Lake-A Case Study of Lake Qinghai, China. Climate Change, 39, 695-714. https://doi.org/10.1023/A:1005319616456

[22] Altun, O.A. (1960) Hydrological Chemistry Principles. Geology Press, Beijing, 80-115. (In Chinese) 
[23] Sun, D.P., Tang, Y. and Xu, Z.Q. (1991) Preliminary Study on the Chemical Evolution of Lake Qinghai. Chinese Science Bulletin, 15, 1172-1174.

[24] Gibbs, R.J. (1970) Mechanism Controlling Word Water Chemistry. Science, 170, 10881090. https://doi.org/10.1126/science.170.3962.1088

[25] Meybeck, M. (1987) Global Chemical Weathering of Surficial Rocks Estimated from River Dissolved. American Journal of Science, 287, 401-428. https://doi.org/10.2475/ajs.287.5.401

[26] Zhu, B.Q. and Yang, X.P. (2007) The Chemical Characteristics and Causes of Natural Water in Taklimakan Desert. Chinese Science Bulletin, 52, 1561-1566. (In Chinese)

[27] Lanzhou Branch Chinese Academy of Science (1994) Evolution of Recent Environment in Qinghai Lake and Its Prediction. Since Press, Beijing, 10-13. (In Chinese)

[28] Yi, W.J., Li, X.Y., Cui, B.L., et al. (2010) Climate Change and Impact on Water Level of the Qinghai Lake Watershed. Journal of Arid Meteorology, 28, 375-383. (In Chinese)

[29] Ding, Y.J. and Liu, F.L. (1995) Effect of Climatic Change of Water Balance of Qinghai Lake Basin for Recent Thirty Years and Possible Tendency. Scientia Geographica Sinica, 15, 128-135. (In Chinese)

[30] Shi, Y.F. (1990) Glacier Recession and Lake Shrinkage Indicating the Climatic Warming and Drying Trend. Acta Geographica Sinica, 45, 1-13. (In Chinese)

[31] Liu, J.F., Huo, S.Q., Li, S.J., et al. (2007) Application of SWAT Model to Analysis of Runoff Variation of Buha River Basin of Qinghai Lake. Journal of Hohai University, 35, 159-163. (In Chinese)

[32] Arnold, J.G., Allen, P.M. and Bernhardt, G. (1993) A Comprehensive Surface Groundwater Flow Model. Journal of Hydrology, 142, 47-69. https://doi.org/10.1016/0022-1694(93)90004-S

[33] Pinto, J.G., Fröhlich, E.L., Leckebusch, G.C. and Ulbrich, U. (2007) Changing European Storm Loss Potentials under Modified Climate Conditions According to Ensemble Simulations of the ECHAM5/MPI-OM1 GCM. Natural Hazards and Earth System Sciences, 7, 165-175. https://doi.org/10.5194/nhess-7-165-2007

[34] Roeckner, E., Bäuml, G., Bonaventura, L., et al. (2003) The Atmospheric General Circulation Model ECHAM5. Part I: Model Description, MPI Report, 249.

[35] Wilks, D.S. (1989) Statistical Specification of Local Surface Weather Elements from LargeScale Information. Theoretical and Applied Climatology, 40, 119-134. https://doi.org/10.1007/BF00866175

[36] Storch, H.V. (1999) On the Use of "Inflation" in Statistical Downscaling. Journal of Climate, 12, 3505-3506. https://doi.org/10.1175/1520-0442(1999)012<3505:OTUOII >2.0.CO;2

[37] Zorita, E. and Storch, H.V. (1999) The Analog Method as a Simple Statistical Downscaling Techniqu: Comparison with More Complicated Methods. Journal of Climate, 12, 24742489. https://doi.org/10.1175/1520-0442(1999)012<2474:TAMAAS >2.0.CO;2 
Submit or recommend next manuscript to SCIRP and we will provide best service for you:

Accepting pre-submission inquiries through Email, Facebook, LinkedIn, Twitter, etc. A wide selection of journals (inclusive of 9 subjects, more than 200 journals)

Providing 24-hour high-quality service

User-friendly online submission system

Fair and swift peer-review system

Efficient typesetting and proofreading procedure

Display of the result of downloads and visits, as well as the number of cited articles

Maximum dissemination of your research work

Submit your manuscript at: http://papersubmission.scirp.org/

Or contact ns@scirp.org 